\title{
"Not a new pattern": Black farmers' perspectives on barriers to participating in federal farm programs
}

\author{
Kelli J. Russell a \\ Mississippi State University \\ Leslie Hossfeld $\mathrm{b} *$ \\ Clemson University \\ Gina Rico Mendez ${ }^{c}$ \\ Mississippi State University
}

Submitted January 2, 2021 / Revised March 1, May 12, and May 24, 2021 / Accepted May 24, 2021 /

Published online August 31, 2021

Citation: Russell, K. J., Hossfeld, L., Rico Mendez, G. (2021). “Not a new pattern”: Black farmers'

perspectives on barriers to participating in federal farm programs. Journal of Agriculture, Food Systems,

and Community Development. 10(4), 195-209. https://doi.org/10.5304/jafscd.2021.104.007

Copyright (C) 2021 by the Authors. Published by the Lyson Center for Civic Agriculture and Food Systems. Open access under CC-BY license.

\begin{abstract}
Although there are more opportunities and revamped avenues for socially disadvantaged farmers to participate in federal agricultural program since Pigford v. Glickman, the first Black farmer class action lawsuit against USDA and subsequent billion dollar settlement, there is not a lot of scholarly research on Black farmers' perspectives
\end{abstract}

${ }^{a}$ Kelli J. Russell, Ph.D. Candidate, Department of Sociology, Mississippi State University; 456 Hardy Road; Starkville, MS 39759 USA; kmj104@msstate.edu

$\mathrm{b} *$ Corresponding author: Leslie Hossfeld, Professor of Sociology and Dean, College of Behavioral, Social and Health Sciences, Clemson University; 201 Epsilon Zeta Drive; Clemson, SC 29634 USA; 1hossfe@,clemson.edu

c Gina Rico Mendez, Assistant Research Professor, Social Science Research Center, Mississippi State University; 1 Research Boulvard., Suite 103; Mississippi State, MS 39762 USA; gina.mendez@ssrc.msstate.edu and experiences in accessing and using these programs today. Using data from nine focus groups in Mississippi with 89 Black farmers, we find that Black farmers and ranchers identify several barriers to program participation, namely communication about programs and problems with the application and approval process, including a lack of standardization and transparency. Inter-

\section{Funding Disclosure}

The research for this paper was supported by the Alcorn State University-Socially Disadvantaged Farmers and Ranchers Policy Research Center, through the project "Accessing Government Assistance for Socially Disadvantaged Farmers," U.S. Department of Agriculture National Institute of Food and Agriculture (USDA NIFA), led by Dr. Leslie Hossfeld, PI. PTE Federal Award No. 68-3A75-17-139. Any opinions, findings, conclusions, or recommendations expressed in this publication are those of the authors and do not necessarily reflect the view of Alcorn State University or the U.S. Department of Agriculture. 
woven throughout the discussions of barriers were conversations about racial and gender discrimination, with producers soundly in agreement that the former persists, and the latter is an issue. This research informs our understandings of Black farmers' experiences of how racial hierarchies and networks continue to shape their ability to access and participate in federal farm programs; policy recommendations are provided.

\section{Keywords}

Socially Disadvantaged Farmers, Black Farmers, Federal Farm Programs, USDA, Race, Agriculture, Black Agrarianism, Rural Development

\section{Introduction}

Census of Agriculture data show that agricultural production remains an industry populated and dominated by White men (U.S. Department of Agriculture [USDA], 2014a). In addition to only making up a minor sector of the industry, Black farm operators, on average, have smaller farms, incomes, and smaller amounts of government payments and loans when compared to White farmers (Jones, 1994; USDA, 2019b). USDA refers to these producers-Black farmers - as socially disadvantaged farmers and ranchers. ${ }^{1}$

In studying Black farmers and ranchers, ${ }^{2}$ scholars have focused on the skewed demographics in agriculture (Horst \& Marion, 2019; Luster \& Barkley, 2011; Molnar et al., 1988), the relationship between heir property and race (Balvanz et al., 2016; Dyer \& Bailey, 2009; Gilbert et al., 2002), Black farmers' relationship with USDA (Cowan \& Feder, 2013; Dishongh \& Worthen, 1991; Tyler \& Moore, 2013; Tyler et al., 2014) and the need for structural and practical changes in agriculture and federal farm programs (Brown et al., 1994; Grant et al., 2012). There is also an existing and growing body of research highlighting the works of resistance, activism, and pursuits of justice through agriculture and food systems by farmers of color (Alkon \& Agyeman, 2011; Thompson, 2011;
White, 2018). Black farmers' current perspectives on new and existing barriers to participation in USDA farm programs is a topic that is less explored in peer-reviewed sociological literature. While general impediments stemming from structural racism are often referred to abstractly in research, little contemporary scholarship empirically addresses the specific barriers after the creation of the Office of Civil Rights at USDA in 2002 and amid USDA's ongoing efforts to improve outreach efforts to Black farmers during the last decade after the advent of funding for the Office of Advocacy and Outreach in the 2008 farm bill.

Hence, the aims of this research are to first understand if there are any current barriers to participation in USDA farm programs for Black farmers, and secondly, if so, what some of the barriers they encounter are when applying for and using federal agricultural programs. To do this, we focus specifically on USDA conservation programs administered by the Natural Resource Conservation Service (NRCS). Through data from nine focus groups with 89 Black producers in Mississippi, the findings of this research describe the presence of multiple, ongoing barriers to participation in federal farm programs for Black farmers and ranchers.

\section{Background}

\section{Federal Farm Conservation Programs}

To fund the various programs administered by USDA, the U.S. Congress passes the farm bill every five years (Johnson \& Monke, 2019). Title II of the farm bill focuses on conservation programs. First included in the Food Security Act of 1985 (the 1985 farm bill), conservation programs now make up an important part of the farm bill spending (Stubbs, 2016). According to the 2021 USDA budget summary, farm bill allocation for FY 2021 conservation programs under the Natural Resource Conservation Service (NRCS) is US \$3,958 million (USDA, 2021). The USDA's original conservation

\footnotetext{
${ }^{1}$ In some portions of the farm bill, the group definition of socially disadvantaged farmer or producer includes women. In this paper, we are explicitly only focusing on the experiences and perspectives of Black men and women who farm or ranch.

${ }^{2}$ Because the individuals at each focus group would use different terms to describe themselves—rancher, farmer, producer, farm operator-we also use the terms interchangeably in this paper.
} 
programs focused on soil erosion and water quality and quantity issues, whereas the current farm bill also includes conservation provisions for air quality, wetlands restoration and protection, energy efficiency, wildlife habitat, and sustainable agriculture (Stubbs, 2016, 2017). Although the Farm Service Agency (FSA), a subagency of USDA, oversees the Conservation Reserve Program, a different subagency, the NRCS, administers the vast majority of USDA's conservation programs.

Whereas previous conservations programs were heralded for their environmental benefits alone, current conservation programs are a tool of risk management and a provider of supplemental farm income (Center for Rural Affairs, 2017). Participation in conservation programs is voluntary but encouraged (Stubbs, 2010). Because the ability to secure financial capital and mitigate risk is often difficult for producers, access to conservation program funding is extremely important for disadvantaged producers to be successful in their farming operations during periods of instability.

\section{Agency Structure and Program Application Process} Like several other USDA subagencies, NRCS is decentralized and has field offices in almost every county in the U.S. General agricultural conservation program priorities are decided at a national level and fashioned into a unified strategic plan (USDA, 2011). Specific program funding priorities are not made at the national level. The majority of administrative and programmatic funding decisions are decided on a local, regional, or state level with input from specific local committees of farmers and NRCS staff (Jackson Lewis LLP Corporate Diversity Counseling Group, 2011; Stubbs, 2010).

To apply for a NRCS program, landowners contact their NRCS area conservationist and alert him or her to their interest in participating in conservation programs (Cowan \& Johnson, 2008). The landowner then meets with the area conservationist, files the appropriate paperwork, and the area conservationist then informs the landowner of his or her options regarding funding, programs, and a timeline (USDA, 2015). Applications are accepted at any time during the year, but funding decisions are made according to local deadlines (USDA, 2016). Following current NRCS criteria, local area conservationists then score and rank applications before submitting them to the state conservationist for approval (Jackson Lewis LLP Corporate Diversity Counseling Group, 2011).

\section{Farmers and Ranchers and Federal Farm Programs} The 1990 farm bill introduced the term "socially disadvantaged farmers and ranchers" as a category of farmers and producers eligible for benefits from various farm bill programs. ${ }^{3}$ USDA has a history of civil rights claims from both producers and its own workforce (U.S. Government Accountability Office [GAO], 2008; Vilsack, 2016). The agency that is supposed to be the "People's Department" is also known as the "last plantation" (USDA, 2010). Since the USDA has a history of grievances related to equal opportunity and civil rights, Congress authorized the creation of the Office of the Assistant Secretary of Civil Rights and the creation of the position of Assistant Secretary of Civil Rights (U.S. GAO, 2012). While the creation of the office alleviated some issues immediately, USDA has had slow or no progress at times on remedying the underrepresentation of famers of color in program enrollment (U.S. GAO, 2008, 2012).

Now acutely aware of the inequalities in agriculture, the U.S. Congress and the USDA have hypothesized that the lack of current Black farmers is a result of a lack of financial resources (USDA, 2014b). Additionally, USDA admits that its history of problematic race relations and gender and racial discrimination could be a factor in the low number of women and individuals of color in agriculture (Daniel, 2007; Hill et al., 2013; Vilsack, 2017). Hence, USDA has created new outreach and support programs specifically for individuals of color and women producers and formed new oversight offices. However, the funding disparities between

\footnotetext{
${ }^{3}$ In Section 2501(e)(2) of the Food, Agriculture, Conservation, and Trade Act of 1990 (7 USC 2279(e)(2)), a socially disadvantaged farmer or rancher (SDA) is defined as a farmer or rancher who is a member of a "Socially Disadvantaged Group." For a history of the changes to this definition and how USDA uses the term, please see "Defining a Socially Disadvantaged Farmer and Rancher (SDFR): In Brief' (Congressional Research Service, 2021).
} 
socially disadvantaged producers and their White peers remain.

A few scholars have considered agricultural programs and race or gender collectively (Brown et al., 1994; Johnson \& Ready, 2017; Molnar et al., 2001; Tyler \& Moore, 2013); however, few works have specifically focused on Black producers and conservation funding via the Natural Resource Conservation Service (NRCS) programs, as this study does. Prior to the creation of the Office of Civil Rights and the Office of Advocacy and Outreach at USDA, Dishongh and Worthen (1991) conducted research with Black farmers in Florida regarding their perspectives on NRCS, finding the need for greater accessibility of programs and more outreach initiatives. Only one recent government report examines the barriers for socially disadvantaged and limited resource farmers' enrollment in NRCS agricultural programs (Jackson Lewis LLP Corporate Diversity Counseling Group, 2011). The lack of focus on NRCS programs from the literature limits understanding of agriculture policy because NRCS administers the majority of the farm programs for conservation, small crops, and livestock. This is important because a vast majority of Black farmers and socially disadvantaged producers produce small crops and livestock, not traditional large-scale grain and oilseed crops.

\section{Setting}

Unlike many other industries, agriculture is deeply connected to and dependent on place. Historical, political, economic, social, and physiological factors all influence agricultural production and the use of federal farm programs in a specific place. Here, we argue for the importance of understanding barriers in connection with a specific placeMississippi-and highlight how examining the experiences of Black producers in Mississippi is relevant to our understanding of barriers in other places.

Unlike other states that have large manufacturing or service industries that employ the majority of their state's workforce, agriculture is Mississippi's primary economic activity. Each year, agriculture adds over US $\$ 16.4$ billion into the state's economy (Mississippi State University, 2018). Nearly one-third of Mississippi’s workforce works directly and indirectly in agriculture, and the industry produces $22 \%$ of the state's income (Mississippi Department of Agriculture, 2018). Poultry and eggs combine to make Mississippi's top commodity by value, with forestry, soybeans, cotton, corn, cattle, catfish, sweet potatoes, swine, hay, horticultural crops, and rice rounding out the state's major 12 crops - all with production values of more than US $\$ 100$ million (Mississippi Department of Agriculture, 2018). Distinct from other states that produce a less diverse array of commodities and have fewer types of farm programs, Mississippi produces a variety of highly valued crops. No single commodity or commodity group dominates farm program decision-making or the state's political, economic, and social landscape.

Mississippi is a very diverse state and is currently undergoing demographic shifts. Mississippi has a population of nearly three million; $59.3 \%$ of the state's citizens identify as White, $37.7 \%$ identify as Black, and 3\% identify as Native American, Hispanic or Latinx, Pacific Islander, or a combination of more than race or ethnicity (U.S. Census Bureau, 2017). As Stuesse (2016) stresses, it is important to examine the presence and lack of presence of changes in places like Mississippi where there is racial diversity in addition to well-known and ingrained racial hierarchies.

\section{Historical Problems and Ongoing Efforts}

Mississippi agriculture has been and continues to be controlled by those in positions of privilege (Grim, 2017). Just as those in positions of authority routinely silenced socially disadvantaged producers' voices on the federal policy level, local and statewide agricultural organizations also excluded women and farmers of color from their gatherings and actively worked to limit the influence of women and farmers of color in their local communities and in the statewide political sphere (Reynolds, 2002). In addition to political and organizational discrimination in agriculture in Mississippi, there are numerous historical works that recount the discriminatory practices that individual producers faced in the past (Cowan \& Feder, 2013; Daniel, 2013).

As a result of the agency's problematic history, USDA has focused its efforts on rectifying civil 
rights issues nationally (USDA, 2010; Vilsack, 2016, 2017) and has made specific geographic locations-Mississippi included-the home of pilot projects and in-depth interviews by the Office of Civil Rights in the past (Jackson Lewis LLP Corporate Diversity Counseling Group, 2011; USDA, 2016). Consequently, much is known about Mississippi historically; however, less is known about Black producers' experiences accessing federal programs today.

\section{Current Disparities in Agriculture}

Of the 34,988 farms in Mississippi, only 7.02\% are owned by Black farmers (USDA, 2019a). The disparities are greater when examining what each farm looks like and what it receives from USDA. White farmers in Mississippi receive 94\% of the federal farm payments, with each White-owned farm averaging US\$16,130 in farm program payments (USDA, 2019a). Black-owned farms in Mississippi receive on average US $\$ 7,600$ in farm program payments-only $47 \%$ of White-owned farms' average (USDA, 2019a). The gaps between White and Black farmers found in Mississippi mirror those found nationally; however, the inequalities are larger in Mississippi than in most states (USDA, 2019b).

\section{Applied Research Methods}

Qualitative methods allow for exploration of complex processes (Denzin \& Lincoln, 2011). In traditional sociological research, focus groups have been research outlets to collect and validate individuals' perspectives and experiences in a group setting that emphasizes empowerment through the engagement of marginalized voices (Denzin \& Lincoln, 2011; Kamberelis \& Dimitriadis, 2011). This research builds on that tradition through focus groups with socially disadvantaged farmers closely centering on the research participants' point of view, examining the constraints at play in their lives, and providing robust descriptions of the process(es) influencing their ability to pursue and participate in government agricultural programs through NRCS.
Producers were recruited as focus group participants if they met the following criteria: active producer (sell at least US $\$ 100$ of agricultural products annually), Mississippi resident, over 18 years old, and a member of a socially disadvantaged group under USDA guidelines (see Section 2501(e)(2) of the Food, Agriculture, Conservation and Trade Act of 1990) or worked in the agriculture industry with socially disadvantaged producers and were themselves Black and past producers. Focus groups were conducted in six of the eight Mississippi economic regions, ${ }^{4}$ and all the participants could be classified as one of the following: members of a preexisting regional food hub, loosely connected preexisting agriculture groups, formal agricultural organizations, and individuals with no formal group ties.

Nine focus groups were held across the state with 89 participants in total (66 Black men, 23 Black women) in 2017. Focus groups were conducted at the time and in a neutral location of the participants' choosing. The focus groups lasted 45 to 90 minutes and were recorded with the participants' consent. To allow for the research participants to interject when they felt it was necessary and for the interviewer to ask follow-up, probing questions when needed, focus groups were conducted in a semistructured format.

Questions used in the focus groups elicited information about participant's past experiences, allowing us to discover their meaning-making process around why they farm, their participation or lack of participation in agricultural organizations, their experiences or lack of experiences in applying for and receiving USDA grants and loans, and, finally, their perceptions of the usefulness or lack of usefulness of their social network in the agricultural community. After the conclusion of the focus groups, all the discussions were transcribed and uploaded into MAXQDA Plus (VERBI Software, 2019), a software program used for qualitative coding and analyses. Using a constructivist grounded theory approach, the first author conducted open and selective coding, moving between coding phases throughout the data analysis process

\footnotetext{
${ }^{4}$ The eight Mississippi economic regions as designated by the Mississippi Regional Economic Analysis Project are Northwest, Northeast, Delta, East Central, Capital, Southwest, Pine Belt and Coast (Momentum Mississippi Map, 2017).
} 
(Thornberg \& Charmaz, 2014). The aim of each part of the coding and analysis process was to compare codes and data and vice versa in developing categories and concepts, leading to the emergence of key themes (Charmaz, 2006, 2011).

\section{Results}

Of the 89 focus group participants, the vast majority described themselves small to medium-sized farmers or producers, with $79.8 \%$ owning their own land. Over three-fourths $(76.2 \%)$ of the participants are at least second-generation farmers and $62.1 \%$ had attended college. Many have mixed crop and livestock operations, growing vegetables and goats or beef cattle. Almost all the participants had at least some knowledge of USDA and NRCS, and many had previously applied for or participated in programs administered by USDA.

We found that the overwhelmingly majority of Black farmers we spoke with see many existing and ongoing barriers to participating in NRCS programs. The following sections detail the farmers' discussions on the key impediments-communication, transparency, and uniformity - that farmers considered existing, and ongoing barriers to their successful access and use of NRCS programs. After discussing these specific barriers, we present the farmers' general assessments of racial and gender discrimination.

\section{Barrier 1: Lack of Knowledge about Programs and Poor Communications}

While USDA has a vast list of programs available to producers, almost all farmers shared that a central barrier to using these programs was their lack of knowledge about them. One producer summed this up by saying:

NRCS, yeah, I think it's just a lot of unawareness of what is out there to these rural minority communities probably because the population is just not aware that these offices do these type programs or have these type costshare type programs, and I've mentioned that to people about cost share assistance through NRCS, forestry commission and reservation, and they're like, oh they do that, they just don't understand. I guess it's just a lack of marketing of what these agencies do out in the rural and minority communities. (Group 8:242).

At a different meeting, another farm operator echoed the same sentiment, stating that he felt the lack of marketing was a problem for both USDA and producers:

... There's a group of people that do not know about these programs, and so what is the responsibility of USDA in terms of getting the information out for people to know? Our names are there! We could be on a mailing list if there such a newsletter or mailing list or something going out. But then there's hundreds of other people out there that's not on any list! And they don't get to know unless we share by word of mouth. So, it seems that there is some responsibility for USDA in order to communicate because these programs are for those people in agriculture production. (Group 5:163)

In a lengthy conversation about USDA's communication methods, producers repeated the same sentiment: “There are programs we don't know about" (Group 1:317). The "we" he referred to was not farmers in general; "we" specifically meant Black farmers. Black famers argued that USDA's communications efforts are lackluster at best. Producers collectively argued that without better communications, via paper or electronic means, USDA is not able to serve farmers well or equitably. Unless producers know about the availability of the programs, the current wellintended new policies are useless to them. For the focus group participants, USDA's inability to reach farmers with the information of the programs was an initial hurdle.

\section{Barrier 2: Lack of Transparency}

In addition to being critical of USDA's communications and marketing outreach efforts, the producers repeatedly expressed a concern with the lack of transparency at USDA. Specifically, they shared concerns regarding the availability of programs, application process for programs, and approval of programs when they contacted or visited a NRCS 
office. Numerous producers specifically used the word "hidden" referring to their experiences trying to learn about or apply to programs.

\section{Transparency in the availability of programs}

When discussing the difficulty of learning about programs when visiting a county office, one producer exclaimed: "It's like it's hidden unless you push the right button” (Group 10:112). Similar to USDA's inadequate communications efforts, producers shared that in-office interpersonal communications lacked clarity and transparency.

One focus group participant elaborated on how the availability of programs lacks transparency, stating:

I just don't think the information is there, necessarily, unless you know what you're looking for that little, there's a missing link there. It's not that you go in, and they say "Well, we have a lot of programs available! What are you interested in?" or "Let me see what type of farm you have." Or, "Let me have the opportunity to go out to your farm and see what we can help you with!" I don't necessarily see that. (Group 3:266)

A woman producer further shared that she believed you needed to be extremely direct to overcome the lack of transparency:

Some of the offices that I have been in, like he was saying, you have to have a direct question. If you just going in there, and you are wanting general information-they don't really voluntarily give you anything. So unless you can be specific, you get the run-around. If you go in there almost with a list, and say "look I have already written this down what can you help me with on this list?" you stand a little bit better of a chance. But, if you go in there saying, you know, "I am new. I interested. I was wondering what all programs you have available?" they may tell you "one," knowing all along there is a list over here this long. Now I have sort of a problem with that and their customer service skills. (Group 11:94)
Likewise, at a separate focus group meeting one farmer recalled how he went into his local office and asked specific questions about the availability of funding for certain programs. He wanted county-specific information-information only readily available in the county office. The producer shared his questions with the focus group:

I want to know how much our county gets for money for things for farms any kind of subsidy anything. I want to know what they're getting. I want to know where the money's going. I want to know why the farmers who need it are not getting it ... because everything here is bidden. (Group 4:237)

Answering him, another producer said:

Yeah, you don't know what you get! You might go in there, "I need to plant 10 acres of rye grass." He says, "oh, we out of money." But, how much money did you have? (Group $4: 240)$

At every focus group, Black farmers shared stories of learning about certain programs, only to call or walk in the office and be told "no funding was available," which led them to conclude, as one man summed up, "discrimination is alive and well ... but it is very hidden to a point" (Group 1:235).

Understandably, farmers across the focus groups shared their recurrent disappointment in trying to work in the local office to learn about the availability of programs, program deadlines, and program funding, only to feel more frustrated when they finished than before they began. Hence, producers shared that now they often "don't bother" (Group 1:274) or have "given up" (Group 4:233) when trying to learn about programs inoffice because the information is just "hidden" to them due to their race, gender, or their intersection.

\section{Transparency in the application process}

While several producers wanted information on how the funding process worked and what programs were available, others mentioned transpar- 
ency problems during the application process. Describing the application process, one producer said:

It was awful, it was intrusive, it was absolutely awful and to be treated as if, you know, I don't know. It's just funny when you're trying to get services from somebody and somebody's sitting behind a table who's a farmer who knows the deal, right? These people who sit behind the desks, they're farmers- they own acreage, they own livestock and they do this stuff-so when you come in not knowing exactly what it is that you need, well, they could easily bridge that for you, be like "this is what you're talking about, so then let me give you a picture of how this really works" and then explain it to you. (Group 10:140)

This producer stressed that the individual in the office "knows the deal," yet failed to help the producer make sense of it. He emphasized how he and the individual working in the office are similar-they are all farmers - and yet this person would not help him as a Black producer. Transparency in the process - the "picture of how it really works," as the producer stated-is what the producers and farmers need. While some producers shared that there was little to no transparency in the application process, others stated that things were clear only to a point.

Even when asking specific questions, farmers shared that they felt they were given unintelligible or non-answers about navigating the application steps. This lack of transparency about the process serves to discourage producers over time. A farm operator described her frustrations:

We went in for one service and it was like we were dragged through the mud for three months, but we don't have that kind of time to go in and out of an office. We have crops! We have harvesting, planting. There's so much to do, and to waste three months of your time when that person knows from the beginning what you need to accomplish and fulfill that application to get your request. We felt like we were dragged through the mud for three months. (Group 10:137)

The focus group participants frequently accentuated that they were not sure exactly how the process worked. They often wanted more information on how the funding and application process functioned, but when they asked questions, they still felt everything was "hidden." Similar to producers who became discouraged when trying to gain answers about available programs, producers shared that they sometimes quit during the application process because the lack of transparency and openness made it not worth "fooling with it" (Group 4:142).

\section{Transparency in the approval process}

Sharing his frustration with the approval process and the lack of transparency in the ranking process, whereby applications are scored according to criteria created by the NRCS and top-scoring applications are awarded funding, one producer stated that the employees specifically do "hidden type things" (Group 1:217) when they fail to share with producers how the ranking process works and how to increase their rankings. The majority of other producers at the focus groups agreed. They characterized the approval process as murky at best and infuriating at worst.

At one focus group, when the interviewer asked participants to share the process of working toward an application approval with the local office, a farmer laughed, turned to the focus group leader, and replied, "Can you help us understand why?" The producers largely were unaware of why their applications were not approved or how they were ranked within their county. One farmer described the frustration: "And they got a point system. If you a vet, you get so many points. Or, if you a first-time farmer, so I don't know exactly how, I don't know who else apply, but when I apply—why I didn't get it, I don't know" (Group 7:206).

Others also disclosed that they did not understand the points system. For example, one man shared, "I have got practice for NRCS. And, I have been turned down. I have been turned down for more practices than I got. Mostly because I didn't 
have enough points, they say, but, overall, I guess it's all right, but I could be better" (Group 9:89). Though he phrased it politely_-"enough points, they say"- - this producer's comments, like others', highlights that he is unfamiliar with why his application was denied. He consequently does not know how to improve his application for future rounds of programs.

\section{Barrier 3: Lack of Uniformity}

In addition to communication and transparency being central barriers, producers also articulated that the lack of uniformity among USDA offices and program offerings across counties was frustrating. Because the communications from USDA are limited and the program information, program application, and program approval process are not transparent, local offices operate with a great deal of autonomy, for better or for worse, when it comes to the experiences of Black farmers and producers. The focus group participants spent a lengthy amount of time discussing the variances between county offices and offerings. One farmer shared:

I would clone the process and the people in the office [laughs] so it would be the same. Every office is different, you know. I've been blessed $\ldots$ and [in] other offices, people have told horror stories. ... [So I'd make changes] so that every office would be the same and they know how to treat people, the procedure, all procedures are the same information, if that were possible. (Group 5:217)

Uniformity across offices in specific program offerings and deadlines, they stressed, would help with communication and transparency issues. Nevertheless, several producers did not have high hopes that it would change because of the longevity of the dysfunction between federal policy and the local dissemination of resources:

Well, for all federal program[s] — that's the way it is. It's great at the federal level, and I'm sure even at the state level, but when it gets out in the field - it never gets carried out. You know, it worked its ways back in the '50s, ' $60 \mathrm{~s}$, '70s,
80 s, and in a way it's still happening today to a large degree. (Group 10:170)

It doesn't get carried out well on the local level because:

But the wall has always been when you walk in, "we don't have any money." We don't have any money for that and you would see wells going up all over the place and how are all these people getting wells but we don't have any money. And so that's changing slowly but because it's a county system it just depends on the county in which you live. (Group 2:96)

Numerous focus group participants acknowledged that when considering the vast differences in experiences between county offices, they were often unsure if their office was staffed with "lazy workers" who "just purely don't know" (Group 7:254) or individuals discriminating against them due to their gender or race or the intersection of the two.

\section{Barriers, Bias, and Discrimination}

The focus group participants discussed these three barriers and challenges in their efforts to secure NRCS conservation funding. When talking about their goals of pursuing financial stability and environmental sustainability, farmers mused that to accomplish those things, they needed the assistance of USDA. However, farmers consistently shared that they had difficulty navigating the processeven after the creation of programs for socially disadvantaged producers. One producer remarked that he just wanted someone to "take a chance" on him (Group 4:252). In talking about his wish for that chance, he stated that he wanted to try to impress this upon the USDA employees and wished that they'd say back to him in response:

"Yeah! Like, this guy we know can pay back this loan. His credit's not the best, but we're going to help him out because it's going to help him in the long run by increasing his credit. Plus if he fails on it, he can sell the tractor. It's not like it's going to go anywhere." But, I mean the thing is you're giving this man 
a chance to improve his family, to improve his life, that's what America is supposed to be about. (Group 4:253)

America, he stresses, is supposed to be a meritocracy. It is supposed to be a fair place with no barriers for those who work hard-the American Dream. Instead, he implies that it isn't. It is supposed to be that way, but falls short in numerous ways. Although the producers focused on communication, transparency, and uniformity, sometimes without directly referencing their race or gender, their conversations regarding barriers would slowly shift to structural discussions of their perspectives on racial and gender discrimination occurring within the process.

\section{Racial Bias and Discrimination}

Racial discrimination was implied and discussed by a farmer who said it was "not a new pattern" and that "it's still happening" (Group 10:119-170). Farmers stressed that even with changes, the culture at USDA has not changed. One producer summed up the sentiment when he shared that dealings with USDA went "well right after that Black farmer lawsuit, but right after that, it kind of went right back to the way it used to be" (Group 5:59).

Some farmers argued strongly that the variance in Black farmers' and producers' experiences at local offices was due to the personnel makeup of the office and their autonomy. The producer stated, "Well, obviously, that's why minorit[ies] and women are underserved because the people behind the desk would rather not give us the services" (Group 10:116). Others were even more direct in their arguments. When asked about the differences between offices and if he thought discrimination or bias occurred or occurs in some of them, one older producer shared:

I just can't answer it. I tell you what-if I could change back the hand of time, I'll let you be Black for a year. And then I'll be White and see where I get and where you get.

Because, okay, you lived the White life. I have lived the Black life for a long time. Just let me be White for about a year, and you be
Black for a year, and you walk in my shoes and then you will see the true picture. Like, NRCS, you walk in there and you, now a Black woman, says "Yes ma'am, I would like apply for this." Well, they are going to say, "Well, uh, sorry! I can't help you." Now knowing that I come in there-a White male- "uh, yes, I would like to apply for a well, I have been registered." [They would reply,] "Oh yeah, we see you registered. Here is a list of the wells. You call us," and I'll get on this list. And they will say "Yeah, sir, you have been approved for a well!" Come out, and they drill you a well. Now, you, you were White, but you Black now. You are doing the same thing I am doing! Come in there and [you] say, "Yes, I would like to get a well." [They'd reply], "Are you registered?” [You'd reply,] "Yes, I am." [They'd then say,] "Well we don't have no money for a well right now, uh, we can put you on the list." You don't hear from nothing! But then I get a well. How would that make you feel? So, I mean I can't change the hands of time-it is what it is. ..." (Group 2:167)

Many, like the farmer above, fervently argue that if they were White, they would have extremely different experiences when walking into their local office. Another producer put it more mildly when he said that the amount of successful interaction and program approval for a socially disadvantaged farmer or producer was dependent on "the personality of that office" (Group 5:159). His comment was a polite way of indicating that interactions were dependent on how overtly racist or not a person in the office acted when working with farmers of color.

Regardless of the exact reason for the discriminatory treatment, farmers repeatedly argued that the status quo at USDA has not changed. One farmer explained:

Well, it's not a new pattern, right? I mean this is structural and institutional racism, you know ... but it doesn't really make anybody, you know, change legislation. But you can't change heart, and if people are somehow 
deeming you unworthy, then you know, what's your defense against that? (Group 10:119)

Racial discrimination-individual, institutional, and structural — these farmers concluded, is the root cause of the barriers. The barriers stem from the decentralized structure of USDA where farmers are dependent on their local office for information, rather than a centralized system that is not dependent on local personalities, local networks of power, and local committees' decision-making. 'Though producers' openness in discussions on racial discrimination varied, not a single participant in any of the focus groups vocally disagreed with the perspective that racial discrimination in some fashion exists in some if not all NRCS offices. Conversations on the topic of racial discrimination during the focus groups would drift until they reached suggestions for improvement-namely, making the policies, procedures, programs offered, and practices of each UDSA office uniform and limiting the power of local office personnel and stakeholders as gatekeepers to accessing and participating in programs.

\section{Gender Bias and Discrimination}

The focus group participants largely ignored questions on gender and issues overtly related to gender. Although there were a substantial number of women at the focus groups, the conversations predominantly trended toward discussions of racial discrimination, not gender. Nevertheless, there were several women who highlighted the double difficulty of being a woman of color in agriculture. One producer said that even though in theory she should have better "options" when applying for programs, since USDA has specific outreach programs for women and for farmers of color, there are large hurdles:

The issue that I have is we're not given the option. If I come in and I promise you things and I don't deliver on my promise, I can full understand you not wanting to see me, deal with me, whatever. But when I walk in the door and you have a bias that I am not going to do what I say and you have never seen me, don't know me, don't know anything about me, but your mind is closed when I walk in the door, that is a problem! And, when I walk in the door and you tell me there is no money, and I see ten other people getting the same money that I just asked you for-and the difference is this for me and the fact that your gender is different than my gender, I can put two and two together and come up with four. (Group 2:164)

Just as this woman was confident her gender was a factor in her inability to participate in NRCS programs, other women questioned the salience of gender in comparison to their race. Many women of color were vague in their discussions of gender, musing that "I don't know why" (Group 3:144) it was difficult to work with the staff-Was it their gender or their race, or the intersection of both? Dissecting the intersection of race and gender in interactions with UDSA was complicated for the participants during the focus groups. Nevertheless, none of the participants argued that being a woman in agriculture helped their chances of succeeding in securing government funding. One participant said, "that's a lie!" when asked if being a woman in agriculture helps in overcoming barriers (Group 4:145).

\section{Conclusion}

This research provides valuable insight into contemporary discussions of justice in agriculture and Black agrarianism by describing contemporary barriers that farmers of color experience when working to access and participate in federal farm programs. Specifically, we show how Black producers argue that there are still significant barriers to participation in and use of USDA programs, even with new outreach initiatives from USDA and the growing number of farmers of color in the U.S. and amid scholarly and activist calls for change.

Producers argued that they face barriers related to poor communication efforts, a lack of transparency throughout the process, and very little standardization across NRCS offices. Because of the decentralized structure of USDA, in which most programming and funding decisions are made locally, farmers often struggled to navigate local White farming networks and gatekeepers to learn more 
about the programs. When applying for the programs, the structure of USDA again was problematic. USDA's local decision-making model limits means that each office is unique and has its own funding priorities, and with little transparency and standardization, Black farmers' ability to compare experiences across offices and programs to identify and remedy problems is limited.

We argue that examining the perspectives of Black producers in a place like Mississippi-racially diverse, agriculture-centric, and a state with a long history of entrenched racial hierarchies-helps us better understand the barriers that Black farmers face in agriculture. We also highlight that these producers who argued to us that things are "hidden" and "there's a lot of unawareness" are not new or beginning farmers with little cultural, social, or human capital. The producers who shared their perspectives with us are well-connected, educated, and stable farmers with years of experience. Even with generational farming histories and collegeeducated backgrounds as well as new government programs for socially disadvantaged farmers and ranchers, our focus group participants-Black women and men - still shared that they faced significant barriers in accessing government funding. Their perspectives clearly articulate noteworthy barriers to their American Dream in agriculture. The barriers they describe are due to a confluence of historical factors that collectively fashioned and continue to fashion racial and gender biases and discrimination throughout the dissemination of the program information, application, and approval process.

Hence, given the three key barriers (i.e., communication, transparency, and uniformity), and the systemic forms of discrimination highlighted by Black farmers in the focus groups, this study recommends that NRCS continue efforts to work with Black farmers to addresses these impediments. Specifically, we showed that there is a need to improve communication about conservation programs to Black farmers. Strategies to improve communication efforts include: (1) developing close collaborations with community leaders and agricultural organizations because both types of actors can be critical for disseminating information about NRCS programs, deadlines, technical re- quirements of programs, and administrative processes; (2) implementing additional grassroots outreach strategies that connect local producers with local NRCS personnel; and (3) developing targeted local, state, and federal communication strategies.

Regarding concerns about transparency and lack of uniformity, NRCS can improve transparency efforts by informing the public about their resource allocation criteria, estimated amount of resources available per round and program, and specifics about the overall decision-making process. USDA and NRCS can also continue their efforts to increase awareness about the need to augment diversity in local committees and maintain current efforts to increase diversity in the workplace to include greater racial and gender diversity in decision-making instances. Overall, the results from this work in Mississippi show the need to continue federal efforts to improve awareness about funding opportunities and guidelines in addition to the current allocation disparities.

This research complements other recent research with Black farmers regarding agriculture and resistance by providing rich descriptions of the barriers that socially disadvantaged producers still face today. While we argue that one of the strengths of this research is its setting, it is also a limitation, as our focus groups were conducted in a very racially diverse state with only Black farmers. Therefore, these assessments of barriers may vary in locations with smaller populations of Black farmers or places with larger populations of Asian, Latinx, Native American, or Pacific Islander farmers and ranchers. Future examinations of producers' experiences using USDA federal farm programs should examine the experiences of Black farmers in less racially diverse locations as well as the experiences of Latinx, Native American, and Pacific Islander farmers and producers. Additionally, future studies of USDA policies and practices should further examine the role that the local office plays in the implementation of policy.

Regardless of the barriers faced, the producers we spoke with stated that they will not give up on their ambitions to farm. One farmer said that that he goes on because a barrier to USDA program participation "doesn't stop you from keep moving forward. You just have to go ahead and do what 
you're going to try to do" (Group 10:32). Black producers are "moving ahead," sometimes by themselves, and at other times in concert with other farmers of color creating informal and formal networks to advance Black farmers' participation in federal farm programs and knowledge-sharing to further conservation work on their farms. We are left to wonder: What changes will a new decade bring?

\section{References}

Alkon, A., \& Agyeman, J. (Eds.). (2011). Cultivating food justice: Race, class, and sustainability. MIT Press. https://doi.org/10.7551/mitpress/8922.001.0001

Balvanz, P., Barlow, M. L., Lewis, L. M., Samuel, K., Owens, W., Parker, D. L., Marco, M. D., Crowder, R., Williams, Y., Barker, D., Lightfoot, A., \& Ammerman, A. (2016). “The next generation, that's why we continue to do what we do": African American farmers speak about experiences with land ownership and loss in North Carolina. Journal of Agriculture, Food Systems, and Community Development, 1(3), 67-88. https://doi.org/10.5304/jafscd.2011.013.011

Brown, A., Christy, R. D., \& Gebremedhin, T. G. (1994). Structural changes in U.S. agriculture: Implications for African American farmers. The Review of Black Political Economy, 22(4), 51-71. https://doi.org/10.1007/BF02689979

Center for Rural Affairs. (2017). Farm bill fact sheet: Conservation priorities.

Charmaz, K. (2006). Constructing grounded theory: A practical guide through qualitative analysis. Sage.

Charmaz, K. (2011). Grounded theory methods in social justice research. In N. K. Denzin \& Y. S. Lincoln (Eds.), The Sage handbook of qualitative research (4th $\mathrm{Ed}$.). Sage.

Congressional Research Service. (2021). Defining a socially disadvantaged farmer and rancher (SDFR): In brief (CSR Report No. R46727). https://www.everycrsreport.com/files/2021-03-19 R46727 200ac4f11846453109b2e3e2825b694aa07f4c05.pdf

Cowan, T., \& Feder, J. (2013). The Pigford cases: USD A settlement of discrimination suits by Black farmers (CRS Report No. RS20430). Congressional Research Service. Retrieved from the National Agriculture Law Center: https://nationalaglawcenter.org/wp-content/uploads/assets/crs/RS20430.pdf

Cowan, T., \& Johnson, R. (2008). Agriculture conservation programs: A scorecard (CRS Report No. RL32940). Congressional Research Service. https://www.everycrsreport.com/reports/RL32940.html

Daniel, P. (2007). African American farmers and civil rights. Journal of Southern History, 73(1), 3-38. https://www.jstor.org/stable/27649315

Daniel, P. (2013). Dispossession: Discrimination against African American farmers in the age of civil rights. University of North Carolina Press.

Denzin, N. K., \& Lincoln, Y. S. (2011). Introduction: The discipline and practice of qualitative research. In N. K. Denzin \& Y. S. Lincoln (Eds.), The Sage Handbook of Qualitative Research (4 ${ }^{\text {th }}$ Ed.) (pp. 1-21). Sage.

Dishongh, G. L., \& Worthen, D. I. (1991). Federal farm programs and the limited resource farmer: A Black perspective. The Rural Sociologist, 11(1), 19-22.

Dyer, J. F., \& Bailey, C. (2009). A place to call home: Cultural understandings of heir property among rural African Americans. Rural Sociology, 73(3), 317-338. https://doi.org/10.1526/003601108785766598

Gilbert, J., Sharp, G., \& Felin, M. S. (2002). The loss and persistence of Black-owned farms and farmland: A review of the research literature and its implications. Southern Rural Sociology, 18(2), 1-30.

Grant, G. R., Wood, S. D., \& Wright, W. J. (2012). Black farmers united: The struggle against power and principalities. The Journal of Pan African Studies, 5(1), 1-22

Grim, V. (2017). Mississippi agriculture. In T. Ownby \& C. Wilson (Eds.), Mississippi encyclopedia (pp. 16-18). University of Mississippi Press.

Hill, W. A., Hishaw, J., \& Hargrove, T. M. (2013). Socially disadvantaged farmer issues can be addressed when diverse frontline agricultural workers proactively work together. Professional Agricultural Workers Journal, 1(1), 3-24. https://doi.org/10.22004/ag.econ.236719

Horst, M., \& Marion, A. (2019). Racial, ethnic and gender inequities in farmland ownership and farming in the U.S. Agriculture and Human Values, 36(1), 1-16. https://doi.org/10.1007/s10460-018-9883-3 
Jackson Lewis LLP Corporate Diversity Counseling Group. (2011). United States Department of Agriculture: Independent assessment of the delivery of technical and financial assistance (civil rights assessment). United States Department of Agriculture. https://www.coalition4change.org/USDA\%20jackson.pdf

Johnson, R., \& Monke, J. (2019). What is the farm bill? (CRS Report No. RS22131). Congressional Research Service. https://fas.org/sgp/crs/misc/RS22131.pdf

Johnson, A., \& Ready, G. (2017). Pathways to land access: A study of the Conservation Reserve Program—Transition Incentives Program in four states. Center for Rural Affairs. https://www.cfra.org/sites/default/files/publications/pathways-to-land-access.pdf

Jones, H. S. (1994). Federal agricultural policies: Do Black farm operators benefit? Review of Black Political Economy, 22(4), 25-50. https://doi.org/10.1007/BF02689978

Kamberelis, G., \& Dimitriadis, G. (2011). Focus groups: Contingent articulations of pedagogy, politics, and inquiry. In N. K. Denzin \& Y. S. Lincoln (Eds.), The Sage Handbook of Qualitative Research (4th Ed.) (pp. 545-561). Sage.

Luster, T., \& Barkley, A. (2011). The economic determinants of the number of minority farmers in the Southeast region of the United States, 1969-1997. The Review of Black Political Economy, 38(1), 83-101. https://doi.org/10.1007\%2Fs12114-010-9082-y

Mississippi Department of Agriculture. (2018). Mississippi agriculture overview. https://www.mdac.ms.gov/agency-info/mississippi-agriculture-snapshot/

Mississippi State University. (2018). 2017 Mississippi agriculture, forestry, and natural resources factbook. Mississippi State University Extension.

Molnar, J. J., Bitto, A., \& Brant, G. (2001). Core conservation practices: Adoption barriers perceived by small and limited resource farmers (No. 646). Alabama Agricultural Experiment Station. http://aurora.auburn.edu/bitstream/handle/11200/4088/BULL0646.pdf?sequence=1

Molnar, J. J., Thompson, A., \& Beauford, E. Y. (1988). Minority perspectives on farming, food, and agriculture. Culture and Agriculture, 9(36), 1-5. https://doi.org/10.1525/cuag.1988.9.36.1

Momentum Mississippi Map. (2017). In Mississippi Regional Economic Analysis Project. https://mississippi.reaproject.org

Reynolds, B. J. (2002). Black farmers in America, 1865-2000: The pursuit of independent farming and the role of cooperatives (RBS Research Report No. 194). U.S. Department of Agriculture, Rural Business-Cooperative Service.

Stubbs, M. (2010). Conservation: A guide to programs. https: $/ /$ digitalcommons.unl.edu $/$ cgi/viewcontent.cgi?article $=1010 \&$ context $=$ crsdocs

Stubbs, M. (2016). Agricultural conservation: A guide to programs (CRS Report No. R40763). Congressional Research Service. http://nationalaglawcenter.org/wp-content/uploads/assets/crs/R40763.pdf

Stubbs, M. (2017). Agricultural conservation: A guide to programs (No. R40763). Congressional Research Service.

Stuesse, A. (2016). Scratching out a living: Latinos, race, and work in the Deep South. University of California Press.

Thompson, D. (2011). "Somos del campo": Latino and Latina gardeners and farmers in two rural communities of Iowa-A community capitals framework approach. Joumal of Agriculture, Food Systems, and Community Development, 1(3), 1-16. https://doi.org/10.5304/jafscd.2011.013.001

Thornberg, R., \& Charmaz, K. (2014). Grounded theory and theoretical coding. In U. Flick (Ed.), The SAGE Handbook. of Qualitative Data Analysis (pp. 153-169). Sage.

Tyler, S. S., \& Moore, E. A. (2013). Plight of Black farmers in the context of USDA farm loan programs: A research agenda for the future. Professional Agricultural Workers Journal, 1(1), Article 6. https://tuspubs.tuskegee.edu/pawi/vol1/iss1/6

Tyler, S. S., Rivers III, L., Moore, E. A., \& Rosenbaum, R. (2014). Michigan Black farm owners' perceptions about farm ownership credit acquisition: A critical race analysis. Race, Gender \& Class, 21(3/4), 232-251. https://www.jstor.org/stable/43496994

U.S. Census Bureau. (2017). U.S. Census Burean QuickFacts: Mississippi. https://www.census.gov/quickfacts/MS

U.S. Department of Agriculture. (2010). Civil rights at USDA: A backgrounder on efforts by the Obama Administration. U.S Department of Agriculture. https://www.nrcs.usda.gov/Internet/FSE_DOCUMENTS/nrcs142p2 011689.pdf 
USDA. (2011). NRCS: Strategic plan 2011-2015. U.S Department of Agriculture.

USDA. (2014a). 2012 Census highlights: Race/ethnicity/gender profile.

USDA. (2014b). 2014 farm bill highlights. http://www.usda.gov/documents/usda-2014-farm-bill-highlights.pdf

USDA. (2015). Natural Resource Conservation Service: Five steps to assistance. USDA. http://www.nrcs.usda.gov/wps/portal/nrcs/detail/national/newsroom/features/?cid=stelprdb1193811

USDA. (2016). EQIP: Mississippi. USDA.

USDA. (2019a). 2017 Census of Agriculture race/ethnicity/gender profile: Mississippi. U.S Department of Agriculture. https://www.nass.usda.gov/Publications/AgCensus/2017/Online Resources/Race, Ethnicity and Gender Profi les/Mississippi/cpd28000.pdf

USDA. (2019b). 2017 Census of Agriculture race/ethnicity/gender profile: United States. U.S Department of Agriculture. https://www.nass.usda.gov/Publications/AgCensus/2017/Online Resources/Race, Ethnicity and Gender Profi les/cpd99000.pdf

USDA. (2021). United States Department of Agriculture FY 2021. Budget Summary. U.S. Department of Agriculture. https://www.usda.gov/sites/default/files/documents/usda-fy2021-budget-summary.pdf

U.S. Government Accountability Office [GAO]. (2008). U.S. Department of Agriculture: Management of civil rights efforts continues to be deficient despite years of attention (GAO-08-755T). https://www.gao.gov/assets/gao-08-755t.pdf

U.S. GAO. (2012). U.S. Department of Agriculture: Progress toward implementing GAO's civil rights recommendations (GAO-12976R). U.S. Government Accountability Office. https://www.gao.gov/assets/650/647696.pdf

VERBI. (2019). MAXQDA [computer software]. Berlin, Germany: VERBI Software. https://maxqda.com

Vilsack, T. (2016). The People's Department: A new civil rights era at USD A. U.S Department of Agriculture. https://medium.com/usda-results/https-medium-com-usda-results-chapter-8-b57f91b64d49\#.j28u2xa26

Vilsack, T. (2017). The People's Department: Growing a stronger and healthier future for America. U.S. Department of Agriculture. White, M. M. (2018). Freedom farmers: Agricultural resistance and the Black freedom movement. University of North Carolina Press. 